Contents list avaliable at Directory of Open Access Journals (DOAJ)
Aulad : Journal On Early Childhood
Vol 3 No 2 2020, Pages 85-94
ISSN : 2655-4798 (Printed); 2655-433X (Online)
Journal Homepage: https://aulad.org/index.php/aulad

\title{
The Early Childhood Educator: A Career of choice beyond the 21st century in Africa
}

\author{
Philomena Chepsiror ${ }^{1}$ \\ Department of Curriculum, Instruction and Educational Media, School of Education, Moi University, Eldoret, \\ Kenya \\ DOI: 10.31004/aulad.v3i2.59
}

Article Info
Keywords:
early childhood,
educator,
career of choice,
unemployment

Kata kunci:

Anak usia dini,

Pendidik,

Pilihan profesi,

Penganguran

\begin{abstract}
Sustainable Development Goal 8 calls for full, freely chosen and productive employment and decent work for all. However, Evidence from statistics shows that employment opportunities have continued to diminish world over and that the shortage of jobs is expected to continue in the near future. Africa bears the brunt for this unemployment situation. The good news however, is that early childhood education (ECE) in Africa is growing in leaps and bounce and is expected to continue growing as awareness around it intensifies. Findings from a critical analysis of pertinent literature, indicate that the rising realization of the importance of ECE, the growing population, improved perception of $E C E$, professionalization of the ECE educator, in addition to mainstreaming, advocacy and positioning of ECE as a priority in national development agendas is evidence that development in the early childhood education might be the magic bullet for the unemployment menace in Africa. The paper was expected to inspire policy makers to step-up investment in early childhood education and mark it as a career of choice for the 21st century and beyond. This review provides an opening toward a broader understanding of the future livelihood chances for an early childhood educator.
\end{abstract}

\section{Abstrak}

Tujuan Pembangunan Berkelanjutan 8 menyerukan pekerjaan menyeluruh, dipilih secara bebas dan produktif serta pekerjaan yang layak untuk semua. Namun, Bukti dari statistik menunjukkan bahwa kesempatan kerja terus berkurang di seluruh dunia dan bahwa kekurangan pekerjaan diperkirakan akan terus berlanjut dalam waktu dekat. Afrika menanggung beban terbesar untuk situasi pengangguran ini. Namun kabar baiknya, adalah bahwa Pendidikan Anak Usia Dini (PAUD) di Afrika tumbuh pesat dan diperkirakan akan terus tumbuh seiring dengan meningkatnya kesadaran di sekitarnya. Temuan dari analisis kritis literatur terkait, menunjukkan bahwa meningkatnya kesadaran akan pentingnya PAUD, populasi yang berkembang, peningkatan persepsi PAUD, profesionalisasi pendidik PAUD, di samping pengarusutamaan, advokasi dan penempatan PAUD sebagai prioritas di tingkat nasional. agenda pembangunan adalah bukti bahwa perkembangan dalam pendidikan anak usia dini mungkin merupakan peluru ajaib bagi ancaman pengangguran di Afrika. Makalah ini diharapkan dapat menginspirasi para pembuat kebijakan untuk meningkatkan investasi dalam pendidikan anak usia dini dan menandainya sebagai karir pilihan untuk abad ke-21 dan seterusnya. Tinjauan ini memberikan celah menuju pemahaman yang lebih luas tentang peluang mata pencaharian masa depan bagi seorang pendidik anak usia dini.

\footnotetext{
${ }^{1}$ Corresponding author at: Department of Curriculum, Instruction and Educational Media, School of Education, Moi University, Eldoret, Kenya Email: chepsirorpj@gmail.com
} 


\section{INTRODUCTION}

Sustainable Development Goal 8 calls for full, freely chosen and productive employment and decent work for all. Earnings from work are the main source of income for most people, making its availability and accessibility a primary concern. (ILO, 2020). However, employment opportunities have continued to diminish world over. Evidence from statistics shows that countries are not experiencing an upward convergence of employment opportunities and that the shortage of jobs is expected to continue in the near future (ILO, 2020). Africa bears the brunt for this unemployment situation. Ighobor (2017) estimates the number of unemployed young people on the continent at nearly $60 \%$. On the contrary, early childhood education career in Africa is growing in leaps and bounce and is expected to continue growing as awareness around it intensifies.

The National Association for the Education of Young Children (NAEYC) defines "early childhood" as occurring before the age of eight. It is during this period that a child goes through the most rapid phase of growth and development. These years are critical because children's brains develop faster than at any other point in their lives. Research has shown that in their fifth birthday, a child's brain is 90\% developed (Rose \& Hewitt (2017). During these years the foundations for their social skills, self-esteem, perception of the world and moral outlook are established, as well as the development of cognitive skills. To allow the brain to grow and the child to develop to their full potential, children need quality nurturing care including play, health, protection, nutrition and early learning.

An Early Childhood Educator is a person who specializes in working with young children and their families - birth through third grade. Meils (2005) asserts that their role consists mostly on providing nursing and instruction in the most basic aspects of formal education. Their primary responsibilities include providing a stimulating, caring, inclusive, safe, and clean environment for infants and toddlers; Assisting in planning, preparing, and implementing a high quality, play-based, developmentally appropriate curriculum to foster physical, cognitive, emotional, and social development and observing, monitoring, and tracking each child's individual progress and development to make sure they work successfully towards achieving pre-established learning and behavioural goals. In order to work as an early childhood professional, one requires certification which is most commonly earned through a training program as designated in individual countries. However, the educator's impact has often been underestimated. The devaluing of the educator working with young children has been extensively documented (Bourgeault \& Khokher 2006; Culkin, 1999; Fuller \& Strath 2001. Yet this workforce has extensive value to society.

This paper highlights social factors drawn from literature that are likely to fast track development in the early childhood education sector and broaden opportunities for employment for over 120 million of the unemployed youth in Africa. It analyzes factors that have promoted the growth of ECE in Africa such as; the realization of the importance of ECE, ECE as a field that is developing, population growth, improved perception of the early childhood educator, professionalization, mainstreaming, advocacy and prioritization of ECE. In essence the paper offers insights that enhance an understanding of dynamics that might shape the future of ECE as a source for careers in the 21st century and beyond.

\section{THEORY}

The study was anchored on the Theory of Change as described by Serrat (2013). Theory of Change is essentially a comprehensive description and illustration of how and why a desired change is expected to happen in a particular context. Concisely, a theory of change explains how and why a sequence of logically-linked pathways of change, should lead to an ultimate outcome. It does so by articulating assumptions and the beliefs and hypotheses they rest on, about how change happens in a specific external context; and stipulating how outcomes toward the change will be brought about and documented with indicators that suggest how much of, for whom, and when each outcome is to be realized.

This study articulated several aspects of social change namely; the rising realization of the importance of ECE, the growing population, improved perception of ECE, professionalization of the ECE educator, mainstreaming, advocacy and positioning of ECE as a priority in national development agendas as indicators assumed as supporting evidence that they are likely to fast track development in the early childhood education sector. The outcome is that if these indicators are constant, there will be an increase in opportunities for employment in Africa.

\section{METHODS}

Data for this study was mainly collected from internet sources. First, an extensive search from published material relevant to the study was made. Then key themes were identified for the study and the material was organized appropriately into these themes. The material was then scrutinized to determine what was relevant to the problem of the study and to determine what was to be included or excluded. The selected literature was assessed, critiqued, and synthesized to generate a new perspective of the topic under study. This helped the reviewer make sound analytical discussions and conclusions concerning the problem of the study. 


\section{RESULT AND DISCUSSION}

\section{Early childhood education: a universal remedy for future unemployment}

Many rigorous and reliable studies have demonstrated that early childhood programs produce very high returns on investment (Bakken, Brown, and Downing. 2017). As adults, children in these programs have greater chances of being educated, employed, and trained in a specific occupation. What's more, they have improved job skills and work attitudes (Barnett, 2008). Discussed below are the aspects that point towards early childhood education as a promising source of human employment opportunities and a magic bullet for the unemployment menace in Africa.

\section{Essentialness of preschool education}

The critical role of early childhood education cannot be overemphasized. Now, more than ever before, educators and policy makers throughout the world are paying unprecedented attention to the quality of education offered to young children because the cognitive, emotional, social and physical development of young children has a direct effect on their overall development and on the adult they will become (Chepsiror, 2019). Early childhood education is encouraged for the healthy development and nurturing of the important foundations for preparing children for formal education and human capital formation (Nores \& Bernet, 2010), and trends show that governments and parents are increasingly recognizing this.

Knowledge from developmental neuroscience, biological science, and epigenetics provides the scientific basis for understanding the importance of early child development (conception to ages 6-8), as the stage that the capacity of a child's brain to soak up new learning. This stage establishes a child's social competence, cognitive skills, emotional well-being, language, literacy skills and physical abilities that affect the next stage of human development, as well as the later stages (Mustard, 2010). This peaks when the child is 3 years old. At this early age, proper health, nutrition and stimulation play a critical role for brain development and well-being. Therefore, a more stimulating and responsive interaction with caregivers has an important role in children's long-term cognitive and socio-emotional development.

Early childhood education also has high economic returns. Carneiro \& Heckman (2003) summarizes the benefits of early interventions clearly in figure 1. It illustrates Carneiro and Heckman's argument, plotting the rate of return to human capital at different periods in the lifespan. Age, the horizontal axis, represents a person's position in the life cycle. Holding other factors constant, the return to a dollar of investment made when a person is young is higher than the return to the same dollar amount made at a later age. The curve shows that early investments produce returns over a longer time limit, and also raise the productivity of later investments: the highest return on investment in education is in pre-primary learning, from ages 0-6 years.

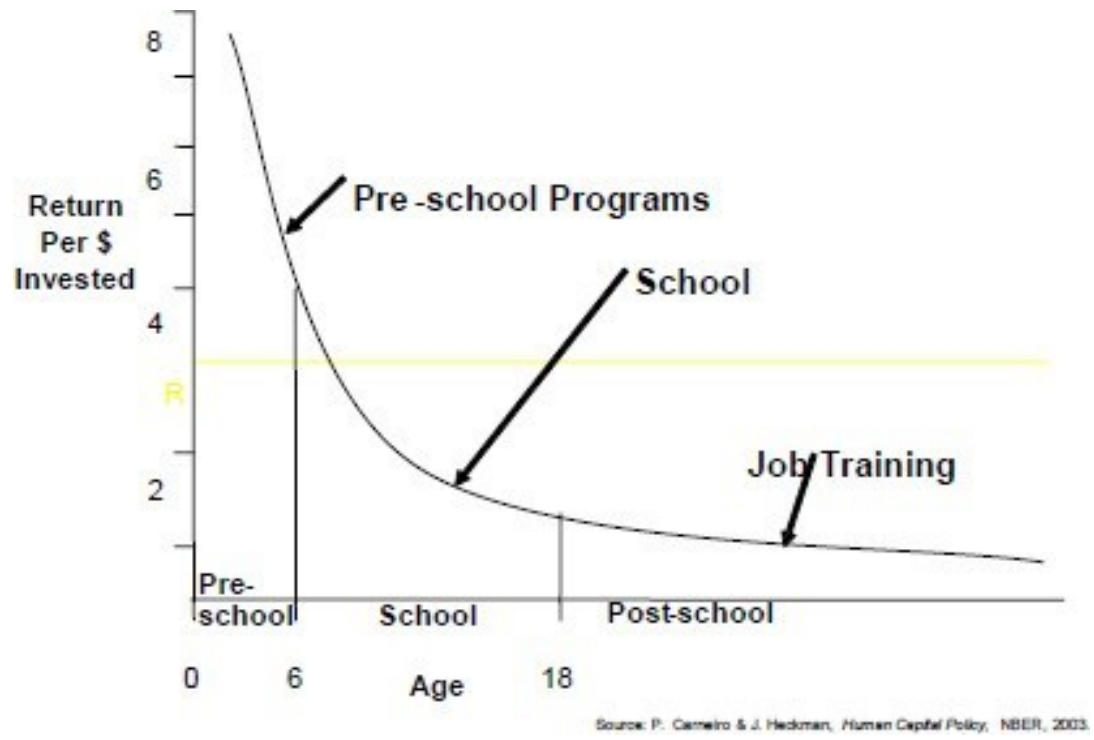

Figure 1. Rates of return to human capital investment. Source: Carneiro \& Heckman (2003)

The benefits accrued from early childhood education cannot be accomplished unless there is a teacher to facilitate it. Teachers give children purpose, set them up for success as citizens of this world, and inspire in them a drive to do well and succeed in life. They have the ability to shape leaders of the future in the best way for society to build positive and inspired future generations and therefore design society, both on a local and global scale (Sharma, 2020). Indeed, teachers have the most important job in the world; to educate the youth in their most impressionable years; they have the power to change lives. In his study, Sutton (2017) found that children from low-income families who received intensive early childhood education went further with their education, had a higher income and better health insurance coverage than those who didn't receive early childhood education. 
Evidence is very promising that as more and more African states realize the importance of early childhood education, and as more parents become aware of the positive impact of quality early childhood programs for the future of their children, more and more of them will enroll their children in pre-school, causing attendance to increase. It follows logically that more educators will be required and therefore a steady employment for qualified preschool teachers is expected to continue. In order to eliminate extreme poverty, boost shared prosperity and create the required human capital African governments must invest in high quality educators capable of meeting the expectation from society of closing achievement gaps and subsequently overturning the poverty levels. They must engage competent educators who will ensure children benefit from the accrued benefits of early childhood education. In the words of Bivens, et al. ( 2016) such endeavors not only afford academic and social-emotional advantages, but they also increase future employment opportunities and earnings. Therefore, it goes without saying that choosing a career in this field is becoming more and more imperative. Becoming an Early childhood educator is inspirational; it makes you help ensure children are equipped with necessary skills for future success; you contribute to high economic returns for the child and the country. As such, the essentialness attached to early childhood education is an indicator that Early childhood education stands to be a career of choice, not only in the 21 st century but also way beyond.

\section{Early childhood education is a growing field}

It is not so long ago in Africa when the concept of pre-school didn't exist. There were no such things as early childhood learning centers since mothers didn't work. Their only job was to stay home to take care of the child and teach him/her important aspects of life. Today the traditional African roles among men and women are rapidly changing. A Modern woman is now a bread winner. It can be reasoned that preschools emerged out of the necessity for a place for children to go while their mothers went to work (Waterhouse,et al 2017).

In the past few decades, there has been a major transfer of child care and early learning from home to institutions. Field evidence supports the argument that the pre-primary and early childhood development services are ready to take off in sub-Saharan Africa in a context of progress in access, growing inequalities and quality challenges. (Zafeirakou, 2015). According to Zafeirakou pre-primary enrollment in Africa, rose by almost two and half times between 1999 and 2015, an increase of 84\%. Zafeirakou applauds some promising progress in seven African countries who have achieved a gross enrollment rate of $80 \%$ or more in pre-primary education: Equatorial Guinea, Ghana, Mauritius, Angola, Cape Verde, the Seychelles and South Africa. This is reason enough to appreciate just how much the early-education landscape has been transformed in Africa over the past two decades and will continue to do so.

For instance, before 1980 in Kenya the economy was still rural-based, and early childhood education did not get much attention. It is only until the industrialization of the country that ECD become an immediate necessity (Mbugua 2009). As industries developed in the urban areas and more Kenyans started to work away from home, the demand for early childhood education increased. The demand has continued to grow especially from the late 1980s when the government assumed responsibility for pre-school education and grew even further after 2010 when the new constitutional dispensation placed the management of pre-school education under the County government. The County Governments have built new ECDE centres, refurbished the existing ones, equipped the ECDE centres, hired ECDE teachers and established feeding programmes especially in arid and semiarid areas. This has led to increased enrolment in the various counties (Sentao Consulting, 2017). Statistical literature reveals that ECDE Net Enrolment Rate (NER), has increased steadily from about $34 \%$ in 2006 to $50 \%$ in 2009; and further to $75 \%$ in 2015 (GoK, 2016).

Another good example of the growth of early childhood education is in Ghana. Kindergarten (KG) enrollment rates have risen substantially. The gross enrollment ratio (GER) grew nearly 12 percentage points between 2005 and 2010, to 93 percent. The substantial increases in enrollment surpassed the national goal for pre-primary enrollment established in the Education Sector Strategic Plan for 2003-2015: 75 percent by 2015. Studies have attributed these increases largely to policy changes. In 2004, the government adopted the National Early Childhood Care and Development Policy, which highlighted access to quality early education as central to improving ECD and learning as well as to reducing inequalities in learning outcomes. The policy incorporated into the free and compulsory basic education system introduced capitation grants (Wolf, et al (2019). This appears to have had a considerable influence on families' decisions to send children to school. As a result, Ghana has one of the highest pre-primary enrollment rates on the continent at 75\% net enrollment in 2015-2016 (Ghana Ministry of Education, 2016).

Overall, ECD has been on an upward trajectory in Africa. As we proceed into the future, the number of children with the need to learn will also continue to increase, potentially at an even higher rate than we are seeing today. Zafeirakou (2015) projects that each job type within early childhood education is expected to grow by 2026. Childcare workers are projected to increase up to $7 \%$. A childcare director job can expect an increase of up to $11 \%$, preschool teachers will grow $10 \%$, kindergarten and elementary teachers will continue to grow up to $7 \%$, and principals are expected to grow up to $8 \%$ by 2026 . What this means is that there will be a continued need for researchers, advisors and teachers with expertise in early childhood education. This means there has never been a better time to enter the early childhood education profession than it is now. Whether one wishes to become a 
preschool teacher or climb the ladder to an administrator position, opportunities will be available well into the future for early childhood education professionals

\section{Career Growth Follows Population Growth: Where ECE Graduates Stand a Chance}

The world's population is growing, but it is in Africa where this is particularly wanton. Statistics produced by the Worldometer (2020) show this exponential growth of the population in Africa. The population was $1,182,438,784$ in 2015, 1,244,222,267 in 2017 and 1,308,064,195 in 2019. This translates to a general change in population to $2.57 \%$ per year. Africa is expected to lead the world in population growth by the end of the century. Chapman (2019) attributes this to two causes; the first is the fact that the average age at which women in Africa become mothers for the first time is more than 4 years earlier than the global average of 26 . The second is the element of high adolescent birth rates. In central and western Africa, for example, it is almost three times the global average.

Population's effects on education and the labor force will influence the opportunities available. In general, the higher the population, the more jobs are created to serve the needs of the many. More homes must be constructed, more food produced, more clothing manufactured and more schools built. This raises the need for higher labor force including employment of more teachers for the schools, starting from pre-school. African countries that are growing more quickly in total population will offer more job opportunities for entry-level learners

Simon \& Pilarski (1979) allude that population increase demands that more schools are opened for the large number of students therein. When numbers increase there are many students of various interests and intellectual capacities. Then it becomes necessary to provide the diverse types of educational opportunities to cater for the needs of different students who will necessarily require a number of experts in order to meet the requirement of developing children of various mental capacities, interests and aptitudes. These include teachers trained for early childhood education, teaching assistants, trained teachers in special needs education, counsellors, and administrators. Indeed the need for these early childhood experts offers a chance for more early childhood professionals to access more job opportunities commensurate with the number and type of learners.

\section{Improved perception of Early Childhood Educator Career}

Beginning from the first gender division of labor in African cultures, many jobs have been divided according to the gender; making some occupations women's job and some occupations men's jobs. Since preschool education traditionally has meant taking care of and feeding young children, this work has been regarded in females' scope (Fagan 1996). However, today both men and women can be seen in non-traditional jobs. For example; there are female soldiers, truck and bus drivers while men are nurses and hotel cooks which are purported to be women jobs. Similarly, there is an increase in the number of men in early childhood education (Cameron, 2001).

Indeed male teachers should be supported as early childhood educators for three main reasons. First, the absence of fathers in children's life. In African societies, there is a rise in the number of children growing up in families with a single parent, usually the mother. There is an emergent need for males to take more active roles in children's lives (Cameron 2001; Haris \& Barnet, 2009). Secondly, males could also be positive role models for little ones. Male teachers and support staff can be taken into account as sources of role models especially for boys. Also, this may help children to develop boys' interests in educational process. Male teachers could also be positive role models for a healthy gender identity and gender- related issues in societies (Cameron, 2001). The last point is gender equality. If the number of male and female teachers could be balanced, this may help children to develop more positive behaviors inside and outside of class settings (Cameron, 2001).

Multiple labels have been applied to describe early childhood educators. Choi (2019) points out three pertinent misconceptions that exist about pre-school teachers. One is that preschool teachers are just babysitters. The truth is that since $90 \%$ of brain development as humans happens predominantly from the ages 0-5 pre-school teachers ensure that children grow in social, emotional, physical, communication and cognition sense. The second misconception is that anyone can be a preschool teacher if they wanted to. The fact is that with the demand for quality childcare, educators undergo rigorous pre-service training and have to go through continuous professional development to stay in the field. Thirdly it is misconstrued that working in childcare means playing with children all day. The reality is that numerous research has placed play at the heart of every child's learning and development. Children not only enjoy play but it is also essential to their development because it contributes to the cognitive, physical, social, and emotional well-being of children and prepares them to succeed in school and in life (Ginsburg, 2013,). As children play they develop language skills; their vocabulary is expanded, they practice using language, learn grammar and sentence construction (Thayer, 2020). In play every activity gives children an opportunity to build their understanding of new concepts, to discover the world and learn how things work as they explore and investigate. They develop skills such as memory, perception, problem-solving, thinking skills (Thayer 2020, Thomsons 1995). 
Since evidence has shown that teaching in early childhood is not just babysitting, both men and women are capable of helping promote brain development of a child. Therefore, both can be trained as childcare educators to promote brain development of the child. Because quality childcare requires rigorous training and continuous professional development both men and women who are grounded in pedagogy and understand how to promote learning and healthy development will take pride in such a job. The fact that child play is critical for every child's learning and development, early learning is thus the responsibility of both men and women. It is through this change in perspective that the rightful place of the early childhood educator is being claimed in the minds of educators, policy makers and states in Africa. The positive change in perception has seen the sector grow in terms of funding and other forms of support, causing its workforce to expand objectively. This makes it the job to watch beyond the twenty first century.

\section{Professionalization of early childhood teaching}

Merriam-Webster's dictionary defines a profession as a calling requiring specialized knowledge and often long and intensive academic preparation. Debates have raged on over and over as to whether early childhood education is/should be a profession. Early childhood education is critical, yet pre-primary teachers are often thought of as babysitters, not professionals. However, the last decade has seen unprecedented international interest in ideas and concepts of professionalism in ECE (Harwood \& Tukonic, 2015; Miller \& Cable, 2011). A growing number of national frameworks and regulatory practices have emerged, as well spaces for educators to engage in discourse about their practice and sense of professionalism (Miller, \& Cable 2011). The argument for high-quality preschool programs is becoming stronger and stronger over time. The quality of provision in early childhood education and care (ECEC) is directly linked to the discussion of professionalism in the workforce (Miller \& Cable, 2011).

A profession is characterized by among other things professional Knowledge, legal guidelines, commitment to the ethical standard and competence (Kile, 2018, Chepsiror, et al, 2012). Professional knowledge is essential knowledge of best practices within a field. Since teaching younger children requires a specialized set of skills, educators working with children in early childhood in Africa, just as it happens globally, typically begin their careers by obtaining a certificate through training at various levels of early childhood teacher education, as well as continuous professional development, as in seminars, workshops and In-service Education and Training (IN-SETs). Such programs are approved by relevant bodies responsible for registration of teacher preparation as required by particular states. To possess professional knowledge teachers are made to earn an understanding of the way children learn and grow, and to apply that knowledge when working with children. They are made aware of issues that affect young children and their families such as legislation that relates to young children, school zonings, or changes in curriculum (Kile. 2018). Kile also contends that trainees undergo training in educational foundations, educational psychology, philosophy, subject content and more importantly pedagogy and practice in teaching, which are the imperative avenues of gaining knowledge in the teaching profession.

Legal guidelines is Kile's next dimension of professionalism. Many states have established a set of standards that guide their early childhood education professionals in high-quality practice and logical expectations for their young children. In Kenya, for example, the 'National Pre-primary education Policy Standard Guidelines' provides specific standards on access, equity and inclusion, quality and relevance, governance and accountability, research, monitoring and evaluation, as well as financing and partnerships (Ministry of Education, 2018). These standard guidelines support practitioners in establishing high-quality programs for early education. It covers a variety of aspects of pre-primary education and care, including curriculum and learning activities, the learning environment, philosophy of care and staffing support.

Kile (2018) also proposes commitment to the ethical standards as a dimension of professionalism. Ethical guidelines describe the responsibilities early childhood education professionals have toward children, families, colleagues and the community. Ghana, for example has a very comprehensive policy that provides a framework for the guidance of Government and all stakeholders in their effort to support the survival, protection and development of the children of Ghana in their early years. It outlines the Government's effort to ensure improved standard of living and enhanced quality of life for families. It comprises of critical strategic direction on creation of appropriate/conducive environment for developing and implementing ECCD programmes, building capacity for ECCD practitioners and institutions, broadening parental participation in the policy implementation process and organizing regular research, monitoring and evaluation programmes (Republic of Ghana (2018). Ghana's standards are hinged on several values and principles including ensuring love and care for children, the best interest of the child being paramount, the child being at the centre of everything, ensuring equal rights for all children and ensuring confidentiality of children.

Competence is Kile's final dimension of professionalism. Collins English Dictionary defines competence as the ability to do something well or effectively. According to Chepsiror (2019), specifies that for teachers to show competence they have to get to know the children in their classroom, to remember their names, get to know their personalities and to find out their preferences. Portraying competence also can include developing a philosophy of education. It includes assessing the growth and development of children, as well as their own growth and development as professionals. These requires a lot of planning, reflecting and thinking. Most importantly, teachers 
can exhibit competence by being capable instructors in the classroom, and to be able to observe and assess children's behavior for use in planning and individualizing curriculum. Because teaching young children is such a highly specialized field, states are raising the requirements for becoming an ECE teacher. In Egypt, for example, the preparation of preschool teachers is at the university level. This is because Egypt believes that the preschool teachers should be highly qualified in professional (educational), academic and cultural fields as he/she is the person capable of instilling the best possible growth of the child.

As a result of professionalization of early childhood education, many African states have established legal guidelines which have enhanced commitment to the Ethical Standards and competence on the job for pre-school teachers. Professionalizing this sector begets assurance of improved quality in the sector. Thus ECE is gaining more reputation and boosted outlook in society. Initiatives of governments are focusing firmly on increasing the quality of the early childhood education and therefore are raising the bar for its workforce. Because of this, early childhood education is arguably becoming, or seems likely to become a profession, putting it at par with other professions and making it as competitive as other forms of occupation and so a popular choice for employment.

\section{Mainstreaming of Early Childhood education}

Mainstreaming early childhood education means giving pre-school children the exact same opportunities as any other child to enjoy every aspect of the school experience. In Kenya for instance, before 1980 preprimary education was exclusively the responsibility of local communities and nongovernmental organizations such as churches, voluntary organizations, local authorities, and individual investors under the auspices of the ministry of Culture and Social Services. In 1980 management of ECD was transferred to the ministry of Education, Science, and Technology through the Presidential Circular No. 1 of 1980. The Ministry of Education then undertook the training of preschool teachers, the preparation and development of the curriculum, and the preparation of teaching materials and is partly paying salaries for teachers through the county governments (Choi, 2005).

In Lesotho the history of ECE started in the 1970 by women organizations known as the Lesotho National Council of Women and the Lesotho Day Care and Community Centre. In the course of providing such useful service, they were of the view that to do the programme justice, there was need for government involvement in Early Childhood Education. This prompted the government to establish ECE as a formal unit of the Ministry of Education whose functions were to develop ECE curriculum, to run in-service training for teachers and caregivers, to develop policy, to monitor and regulate ECE programmes (Mwamwenda 2014).

At attainment of independence in Zimbwabwe in 1980, ECE was placed under the Ministry of Community Development and Women's Affairs. Its role was to develop the curriculum, infrastructure, and teacher education for ECE. By 1988, ECE was placed under the Ministry of Education, Sports, Arts and Culture (Ministry of Education, Sport and Culture 2005). The role of the government was to pay allowances for teachers, supervisors and grants for construction of Centres while NGOs, UNICEF, Plan International and Save the Children were responsible for provision of construction of physical facilities, training of teachers and trainers (Zvobgo, 1990). By 2007, there were as many as $74 \%$ Primary schools which had attached to them ECE Centres (Ministry of Education, 2008). Those attending public rural ECEs do not pay fees, whereas private ECEs charge fees.

As for Uganda Mwamwenda (2014) recounts that prior to Independence in 1962, Early Childhood Education was the function of individuals, families, religious bodies, communities and NGOs (Ministry of Education and Sports, 2007). Given the government negligible role in ECE, the blame in the slow growth of education was placed on the government (Ministry of Education and sports, 2007). As a result, there was a tremendous change in the manner government got involved in ECE, for the past one decade. The government has demonstrated its determination in the promotion of ECE, as it has aimed at founding, owning and administering ECE Centres.

It is instructive to note that with the growing realization that preschool plays an important role in building a child's success in their first years of school, the general outlook of this level of education is changing for the better. Governments have gradually began to mainstream ECDE while they take charge of administration and supervision, training and payment of teachers, preparation and development of the curriculum, and the preparation of teaching materials and sometimes funding for construction of physical facilities. This government facilitation puts ECE at par with other essential sectors of the public service and gives it equal attention. As governments' efforts to offer more robust funding for ECE, it continue to grow and a larger number of opportunities will be created each year for pre-school teaching and other childcare positions. Since this is an area that is still largely untapped early childhood education is expected to continue to offer a livelihood for many for years to come.

\section{Advocacy and positioning of ECD as a priority in national development agendas.}

As human understanding of psychology and human development has become more sophisticated, there has been an increased focus on the importance of early ECD as a time when young brains are developing most quickly forming more than one million connections each second and laying the foundations for the rest of a child's life. Such is the importance of ECD that it was included in the 2015 Sustainable Development Goals (SDGs), confirming its growing significance as part of the global development agenda. Sustainable Development Goal 4 seeks to ensure that, by 2030 , all girls and boys have access to quality early childhood development and care so 
that they are ready for primary education. The SDG framework explains that this goal is critical to ensuring children's long-term development, learning and health. It outlines how investments in young children, yields the greatest long-term impact in terms of developmental and educational outcomes. It also enables early identification of disability, which can lead to better interventions and better learning.

Subsequently in 2009, the African Union (AU) adopted ECD as the 8th priority of the Second Decade of Education for Africa. This was an outcome of the fourth ADEA African Conference on Early Childhood Development that was held in Mombasa (Kenya) under the theme "From Policy to Action: Expanding Investment in ECD for Sustainable Development". This was followed by the official launch of the Mauritius Africa Initiative (MAI) in 2010 which underscored the need for more comprehensive regional approaches and policies for ECCE in subSaharan Africa (Bal, 2019).

Consequently individual African countries have placed ECDE as a priority in their National Development Agenda. In the Social Pillar of Kenya's long-term development blueprint (Vision 2030), for example, integrating early childhood education into primary education is a strategy in the Education and Training sector (Republic of Kenya, 2007). Similarly in Rwanda, the World Bank identified the development of world-class human capital as the first reform priority- with an emphasis on basic education and early literacy. The implementation of these education priorities depends on building a foundation of human capital, which starts with the early stages of education.

With the African countries now focusing on ECD as a major element of national development agenda, it is prospected to cause progress on early childhood education. This underscores the need for more investments in early childhood to support an effective workforce. Once government policies and legislations are fully in place and supported with meticulous implementation and budgetary allocations, then we are good to go; the endeavor to prioritize Africa's Agenda for children, styles working with children a career of choice for now and the future.

\section{CONCLUSION}

It is clearly evident that early childhood education plays an important role in laying the foundation for children to succeed in the future. This industry is poised for continued growth in Africa for years to come and help resolve the unemployment menace. This is based on findings from literature which shows that stakeholders have realized the essentialness of preschool education, leading to an ever-increasing investment in early childhood education programs. As a growing field, there will be a continued need for researchers, advisors and teachers with expertise in early childhood education as well as teachers with a training in special needs education. Besides, ECE graduates stand a chance for employment owing to the rapid increase in population in Africa. Population increase demands that more schools are opened for the large number of students. This offers a chance for more early childhood professionals to access more job opportunities commensurate with the number and type of learners at this level. The improved perception of early Childhood educator is also a boost for the ego for those aspiring for this career especially men This has seen the sector grow in terms of funding and other forms of support, causing its workforce to expand objectively. Furthermore, professionalization of the early childhood career has also seen and will continue to see the sector grow. Professionalizing this sector begets assurance of improved quality in the sector. Thus ECE is gaining more reputation and boosted outlook in society. Finally, it emerged from literature that African governments have begun to mainstream, advocate for and are positioning ECD as a priority in national development agendas. This means that through mainstreaming, just like the government facilitates other public sectors, government takes responsibility for training of preschool teachers, the preparation and development of the curriculum, and the preparation of teaching materials and is paying the salaries of teachers. Furthermore, African states are networking through conferences such as the ADEA to advocate for and fulfilment Sustainable Development Goal 4 that seeks to ensure that by 2030, all girls and boys have access to quality early childhood development and care so that they are ready for primary education,. They are now focusing on ECD as a major element of national development agenda; they are investing in early childhood education as a priority area.

Today's aspiring early childhood educators have a robust career field ahead of them. With a firm understanding of the job and its outlook candidates will be setup for a great deal of rewarding success with today's youngest learners. For those with a love of teaching and helping to shape the lives of children, a career as an early childhood educator might just be a perfect choice. The youth in search of employment and those in school and yet to choose a career, be informed and convinced; there is still a niche for the preschool educator in Africa, chose it, take it!.

\section{REFERENCES}

Bakken, L., Brown, N. and Downing, B. (2017). Early Childhood Education: The Long-Term Benefits. Journal of Research in Childhood Education. https://doi.org/10.1080/02568543.2016.1273285.

Bal,R. (2019). ADEA and the Pivotal Role of Early Childhood Development in Africa: From the Birth of ADEA Working Group on Early Childhood Development to the Africa Play Conference 2019: http://www.adeanet.org

Barnett, W.S. (2008). Preschool Education and Its Lasting Effects: Research and Policy Implications (Boulder and 
Tempe, Ariz.: Education and the Public Interest Center \& Education Policy Research Unit).

Bivens, J., García, E., Gould, E., Weiss, E., \& Wilson, V. (2016). It's Time for an Ambitious National Investment in America's Children (Washington, D.C.: Economic Policy Institute).

Bourgeault, I. L., and Khokher, P. (2006). Making a better living from caregiving: Comparing strategies to improve wages for care providers. Canadian Review of Sociology and Anthropology, 43(4) , 407-425. https://doi.org/10.1111/j.1755-618X.2006.tb01141.x.

Cameron, C. (2001). Promise or problem? A review of the literature on men working in early childhood services. Gender, Work and Organization, 8(4), 430-453. https://doi.org/10.1111/1468-0432.00140.

Carneiro, P. M.,\& Heckman, J. J. (2003). Human Capital Policy (Institute for the Study of Labor (IZA) Discussion Paper No. 821). @ http://papers.ssrn.com

Chapman, W. (2019). Africa to Lead World in Population Growth. U.S NEWS: https://www.usnews.com.

Chepsiror, P. (2019). The Ficus Upshot Model of Reading Development: A Conceptual Analysis. Journal of Education and Practice: https://www.iiste.org

Chepsiror,J. P.et al (2012). Early childhood education teacher professionalism: perspectives and prospects. Semantic Scholar: https://www.semanticscholar.org

Choi,C. (2019). 5 Myths about Preschool Teachers (and What You Can Do About It) https://blog.himama.com

Fagan, J. (1996). Getting males in early childhood programs. Education Digest, 62(2), 24-7

Fuller, B., \& Strath, A. (2001). The child-care and preschool workforce: Demographics, earnings, and unequal distribution. Educational Evaluation and Policy Analysis,23(1), 37-55. https://doi.org/10.3102/01623737023001037.

Ghana Ministry of Education. (2016). Education Sector Performance Report, 2016. Ghana. [Google Scholar]

Ginsburg, K. (2013). The Importance of Play in Promoting Healthy Child Development and Maintaining Strong Parent-Child Bonds.

Government of Kenya. (2012). A Policy Framework for Education: Aligning Education and Training to the Constitution of Kenya (2010) and Kenya Vision 2030 and beyond. Nairobi, Ministry of Education.

Government of Kenya. (2016). Education Sector Report 2017/18-2019/20. Nairobi: Ministry of Education

Haris, K. \& Barnes S. (2009). Male teacher, female teacher: Exploring children's perspectives of teachers' roles in kindergartens. Early Child Development and Care, 179( 2), 167-18. https://doi.org/10.1080/03004430802667005.

Harwood, D., \& Tukonic, S. (2015). The glass ceiling effect: Mediating influences on early years' educators sense of professionalism. Canadian Children, 40(1), 36-54. https://doi.org/10.18357/jcs.v40i1.15210.

Ighobor, K. (2017). Africa's Jobless youth cast a shadow over economic growth. United nations Africa Renewal: https://www.un.org.

International Labour Organization (2020). World Employment and Social Outlook. Geneva: ILO @ https://www.ilo.org

Kile, N. (2018). I'm a teacher, not a babysitter!: Professionalism in early childhood. Retrieved from www.continued.com/early-childhood-education

Mbugua, T. (2009). Teacher Training for Early Childhood Development and Education in Kenya. Journal of Early Childhood Teacher $\quad$ Education, 30(3): https://www.tandfonline.com. https://doi.org/10.1080/10901020903084256.

Meils, J. 2005. The Seven Faces if the Early Childhood Educator. Early Childhood News.com. Excellence Learning Corporation. Available: http://www.earlychildhoodnews.com/earlychildhood/article_view.aspx?Articl elD $=171$

Miller, L., \& Cable, C. (2011). The changing face of professionalism in the early years. In L. https://doi.org/10.4135/9781446288795.n1.

Ministry of Education (2008). Education Facts and Figures 2002-2008

Ministry of Education (2018). The national Pre-Primary Education Policy Standard Guidelines, Nairobi: Government Printer.

MoES, (2007). The early childhood development (ECD) policy. Kampala: MoES.

Mustard, J. F. (2007). Experience-based brain development: scientific underpinnings of the importance of early child development in a global world. In M. E. Young (Ed.), Early Child Development -From measurement to action. A priority for growth and equity (pp. 43-84). Washington, DC: The World Bank.

Mustard, J. F. (2010). Early Brain Development and Human Development. Toronto: http://www.childencyclopedia.com.

Mwamwenda, T.S. (2014). Early Childhood Education in Africa. Mediterranean Journal of Social Sciences 5(20): Retrieved from https://www.mcser.org. https://doi.org/10.5901/mjss.2014.v5n20p1403.

Nores, M. and Bernet, W.S. (2010). Benefits of Early Childhood Intervention Across the world. Economics of Education review 29(2) 271-282. https://doi.org/10.1016/j.econedurev.2009.09.001.

Peisner-Feinberg, E. S., Burchinal, M. R., Clifford, R. M., Culkin, M. L., Howes, C., Kagan, S. L., ... \& Zelazo, J. (1999). The children of the cost, quality, and outcomes study go to school. Chapel Hill, NC: University of North Carolina. 
Republic of Ghana (2018). Early Childhood Care and Development Policy. Ministry of Women and Children's Affairs. Retrieved from https://planipolis.iiep.unesco.org

Republic of Kenya (2007). The Kenya Vision 2030. Nairobi: Government Printer.

Rose, P. and Hewitt, B. (2017). The urgent need for investment in pre- primary education. https://gemreportunesco.wordpress.com.

Sandberg, A., \& Pramling- Samuelsson, I. (2005). An overview study of gender differences in pre-school teachers' attitude towards children's Play. Early Childhood Education Journal, 32 (5), 297-305. https://doi.org/10.1007/s10643-005-4400-x.

Sentao Consulting (2017). Exploring Devolution. A Study of Early Childhood Development Education (ECDE) Service Delivery in Kilifi County. Nairobi: CISP.

Sharma, V.K. (2020). Why are teachers important? Klient Solutech: https://www.klientsolutech.com

Simon,J.L and Pilarski, A.M. (1979). The Effect of Population Growth Upon the Quantity of Education Children Receive. The Review of Economics and Statistics, 61, (4). https://www.jstor.org. https://doi.org/10.2307/1935788

Sutton, A. (2017). What Is the Importance of Early Childhood Education? https://www.hellomotherhood.com

Thayer, A. (2020).The Importance of Play in Early Childhood: www.empoweredparents.co

Thomson, J. (1995). Natural Childhood. New York: Simon \& Schuster.

UNICEF (2011). Ghana: Evaluation of UNICEF's Early Childhood Development Programme with Focus on Government of Netherlands Funding (2008-2010) - Ghana Country Case Study Report. Found at https://www.unicef.org

Waterhouse, P. Hill, A.G. \& Hinde,A. (2017) Combining work and child care: The experiences of mothers in Accra, Ghana, Development Southern Africa, 34:6, 771-786. https://doi.org/10.1080/0376835X.2017.1323627.

Wikipedia (2019). Demographics of Africa. At https://en.wikipedia.org

Wolf, J.S. Aber, L. Jere R. Behrman \& Tsinigo, E. (2019). Experimental Impacts of the "Quality Preschool for Ghana" Interventions on Teacher Professional Well-being, Classroom Quality, and Children's School Readiness. Journal of Research on Educational Effectiveness, 12(1)10-37. https://doi.org/10.1080/19345747.2018.1517199.

Zafeirakou, (2015). Can pre-primary education help solve the learning crisis in Africa?. The World Bank: https://www.globalpartnership.org

Serrat, O. (2013). Theories of change. Manila: Asian Development Bank

Zvobgo, R. 1990. Transforming Education: The Zimbabwean Experience. Harare, Zimbabwe: The College Press 